\title{
Fine root growth and element concentrations of Norway spruce as affected by wood ash and liquid fertilisation
}

\author{
M. Genenger ${ }^{1}$, S. Zimmermann ${ }^{1}$, D. Hallenbarter ${ }^{1}$, W. Landolt ${ }^{1}$, E. Frossard ${ }^{2}$ \& I. Brunner ${ }^{1,3}$ \\ ${ }^{1}$ WSL, Swiss Federal Institute of Forest, Snow and Landscape Research, Zürcherstrasse 111, CH-8903 Birmens- \\ dorf, Switzerland. ${ }^{2}$ Institute of Plant Science, Research Station Eschikon, ETH Zürich, CH-8315 Lindau, \\ Switzerland. ${ }^{3}$ Corresponding author*
}

Received 3 May 2002; accepted in revised form 14 October 2002

Key words: fine root elements, fine root growth, fine root turnover, optimal nutrition, Picea abies, wood ash

\begin{abstract}
A field experiment to test various management practices of sustainable forestry was conducted in a Swiss spruce forest for two growing seasons. Treatments were a control (C), yearly application of $4000 \mathrm{~kg} \mathrm{ha}^{-1}$ wood ash (A), daily irrigation with a steady state fertilisation as 'optimal nutrition' (F) and irrigation with a water control (W). Samples were taken on a $5 \times 5 \mathrm{~m}$ grid once a year with a soil corer to determine fine root biomass $(\leq 2 \mathrm{~mm})$ and soil $\mathrm{pH}$ of the topsoil. A subset of the fine root samples was further analysed for its nutrient composition by $\mathrm{CN}$ and ICP-AES analyses. The dynamics of root growth were observed with the aid of ingrowth-cores after 1, 1.5, and 2 years of treatment and the growth pattern was analysed in terms of biomass, tips, forks, length and root diameter of the samples. The A, F and also the $\mathrm{W}$ treatment resulted in a significant increase of soil $\mathrm{pH}$ in the topsoil. The fine root density increased over the two growing seasons, irrespective of the treatment. The root growth was only slightly different between the treatments with a initially faster growth under the A treatment. The $\mathrm{W}$ treatment reduced the number of root tips and forks, and the root length, while the A treatment increased the number of root tips, forks and the root length, but reduced the diameter. The differences between the three harvesting times (March 1999, October 1999, March 2000) of the ingrowth-cores stressed seasonal differences in root growth and the development of quasi 'steady state' root dynamics. The root turnover was not changed by the treatments. The elements in the fine roots were strongly affected by the treatments $\mathrm{A}$ and $\mathrm{F}$ and sometimes by W. Fine root $\mathrm{N}$ increased with the $\mathrm{F}$ treatment, while $\mathrm{C}$ concentrations decreased under the $\mathrm{A}, \mathrm{F}$ and $\mathrm{W}$ treatments. The $\mathrm{Ca}$ and $\mathrm{Mg}$ concentrations were strongly enhanced by $\mathrm{A}$ but also by the $\mathrm{F}$ treatment. The $\mathrm{K}$ and $\mathrm{P}$ concentrations in the fine roots were improved by all three applications. Due to the $\mathrm{pH}$ increase $\mathrm{Al}, \mathrm{Fe}$ and $\mathrm{Mn}$ concentrations in the fine roots were decreased by the $\mathrm{A}$ and $\mathrm{F}$ treatments. S and $\mathrm{Zn}$ concentrations showed inconsistent changes over the growing seasons. The results of this study were comparable with those of other studies in Europe and confirm the abilities of the fine roots as indicators of forest nutrition, to some extent more sensitive than the commonly used foliar analysis.
\end{abstract}

\section{Introduction}

The consequences of high $\mathrm{N}$ depositions and soil acidification are reported as nutritional imbalances, often deficiencies in Mg, P or K (Hüttl, 1990; Linder, 1995; Matzner and Murach, 1995; Salih and Andersson, 1999; Schulze and Freer-Smith, 1990) in relation to

\footnotetext{
* FAX No: +41-7-392215. Email: ivano.brunner@wsl.ch
}

N. In Switzerland mainly imbalances of $\mathrm{N}$ and $\mathrm{P}$ have been reported in spruce forests (Flückiger and Braun, 1998; Landolt, 1997). To compensate nutritional imbalances of trees and acidification of forest soils, several ameliorating methods have been applied (e.g., Eriksson et al., 1998; Hahn and Marschner, 1998a; Meiwes, 1995; Nilsson et al., 2001; Persson and Ahlström, 1994; Rapp, 1992; Vance, 1996). The effects of wood ash applications on forest soils have 
been studied extensively (e.g., Bramryd and Fransman, 1995; Eriksson, 1998; Kahl et al., 1996; Meiwes, 1995; Vance, 1996), but only few studies have dealt with the effects on the fine roots (e.g., Clarholm, 1998; Persson and Ahlström, 1992, 1994). Another amelioration technique, which has been applied mainly in Scandinavia, is a steady state or compensatory fertilisation, which supplies the nutrients that are needed. The success of this practice is usually monitored by foliage analyses (Linder, 1995). Such a steady state fertilisation can result in a long term amelioration of the nutritional status of the trees, improving the resistance of the forest ecosystem against stress factors (Hüttl, 1990). The hypothesis that fine root-based parameters are suitable as a complement to soil and foliar indicators (Bakker, 1999; Persson et al., 1995) is investigated in the present study.

The 'HARWA' field experiment was established to monitor effects of both wood ash recycling and steady state fertilisation on a forest ecosystem dominated by Norway spruce. In Switzerland at present more than $25000000 \mathrm{~kg}$ wood ash deriving from energy production have to be discarded every year and wood as a renewable energy source is underpinned for the future by forest policy (SAEFL, 1999). Thus, there is a need to evaluate the possibilities of wood ash recycling and to assess the effects of wood ash application in Swiss forests. The objectives of the present study were to investigate within a field experiment the element changes in the fine roots deriving from the ameliorating treatments. Furthermore, possible effects on root growth and root growth dynamics were studied. Together with the soil $\mathrm{pH}$ and element changes in the needles an evaluation of the fine root-based parameters as indicators of plant availability of elements in the forest soil were conducted.

\section{Materials and methods}

\section{Field experiment}

The experiment was conducted in a spruce forest on the Swiss Plateau. The 'Schladwald' (N 47 30'34'/E $08^{\circ} 20^{\prime} 50^{\prime \prime}, 464 \mathrm{~m}$ a.s.1.) forest is located about $25 \mathrm{~km}$ northwest of Zürich, Switzerland. The 70-year-old stand is classified as a Galio odorati-Fagetum luzuletosum (Ellenberg and Klötzli, 1972), dominated by Norway spruce (Picea abies (L.) Karst.). The herblayer vegetation is composed by Anemona nemorosa L., Galium odoratum (L.) Scop., Lamium galeobdolon
(L.) Nath., Oxalis acetosella L., and Rubus fruticosus L. The stand has a density of approximately 440 trees $\mathrm{ha}^{-1}$, with the stems evenly distributed. The soil is an acidic brown earth ('Dystric cambisol', FAO, 1988; compare also Bundt et al., 2001). According to Zimmermann and Frey (2002), the top soil is characterised by: low $\mathrm{pH}$ value (3.5), low $\mathrm{C}\left(44.0 \mathrm{mg} \mathrm{g}^{-1}\right)$ and low $\mathrm{N}$-content $\left(2.7 \mathrm{mg} \mathrm{g}^{-1}\right)$, low cation exchange capacity $\left(96 \mu \mathrm{mol}_{\mathrm{c}} \mathrm{g}^{-1}\right)$ and base saturation (BS, 32\%), low exchangeable base cations $\mathrm{Ca}\left(24.7 \mu \mathrm{mol}_{\mathrm{c}} \mathrm{g}^{-1}\right)$ and $\mathrm{Mg}\left(4.0 \mu \mathrm{mol}_{\mathrm{c}} \mathrm{g}^{-1}\right)$, and high exchangeable $\mathrm{Al}$ $\left(46.3 \mu \mathrm{mol}_{\mathrm{c}} \mathrm{g}^{-1}\right)$. The 15 -year average of annual precipitation is $1076 \mathrm{~mm}$ and of air temperature is $9.6^{\circ} \mathrm{C}$ (SMA, 1998).

The experiment was set up as a random block design with four treatments and four replicated plots resulting in a 0.8 ha investigation area. The plots of each treatment ranged between 200 and $600 \mathrm{~m}^{2}$ in size. The experimental treatments were: a control without any treatment $(\mathrm{C})$, irrigation of stream water (W), irrigation of liquid fertiliser (F), and the application of wood ash (A). The wood ash, deriving from wood chip combustion, was applied by hand on 25 May 1998 and 23 July 1999. The F treatment was based on a nutrient combination according to Ingestad and Lund (1986) related to 70 (1998) or 100 (1999) $\mathrm{kg} \mathrm{N} \mathrm{ha}^{-1}$ (Table 1). The $\mathrm{pH}$ of stream water used for dilution of the fertiliser and for the $\mathrm{W}$ treatment was about 8.5. The wood ash and stream water were analysed, and inputs of elements estimated (F including the contribution of the stream water, Table 1). The $\mathrm{F}$ and $\mathrm{W}$ treatments were irrigated each night from 25 May 1998 to 28 September 1998 and from 6 May 1999 to 27 September 1999 except for days with intensive rain.

\section{Sampling design}

Samples of soil and roots were taken in April in each of the years 1998, 1999 and 2000. The samples were taken independently of the plot design in a $5 \times 5-\mathrm{m}$ grid over the investigation area (Figure 1). At each sampling point three soil cores $(100 \mathrm{~mm}$ depth, diameter $85 \mathrm{~mm}$ ) were collected. The soil consisted of two horizons: Ah (the uppermost mineral soil layer, characterised by an accumulation of humified organic matter) and B (mineral soil layer formed below the Ah horizon), and each horizon from all three cores was pooled separately. The samples were sieved, the fine roots $(\leq 2 \mathrm{~mm}$ ) of Norway spruce were isolated from each bulk sample and washed. The roots were dried 


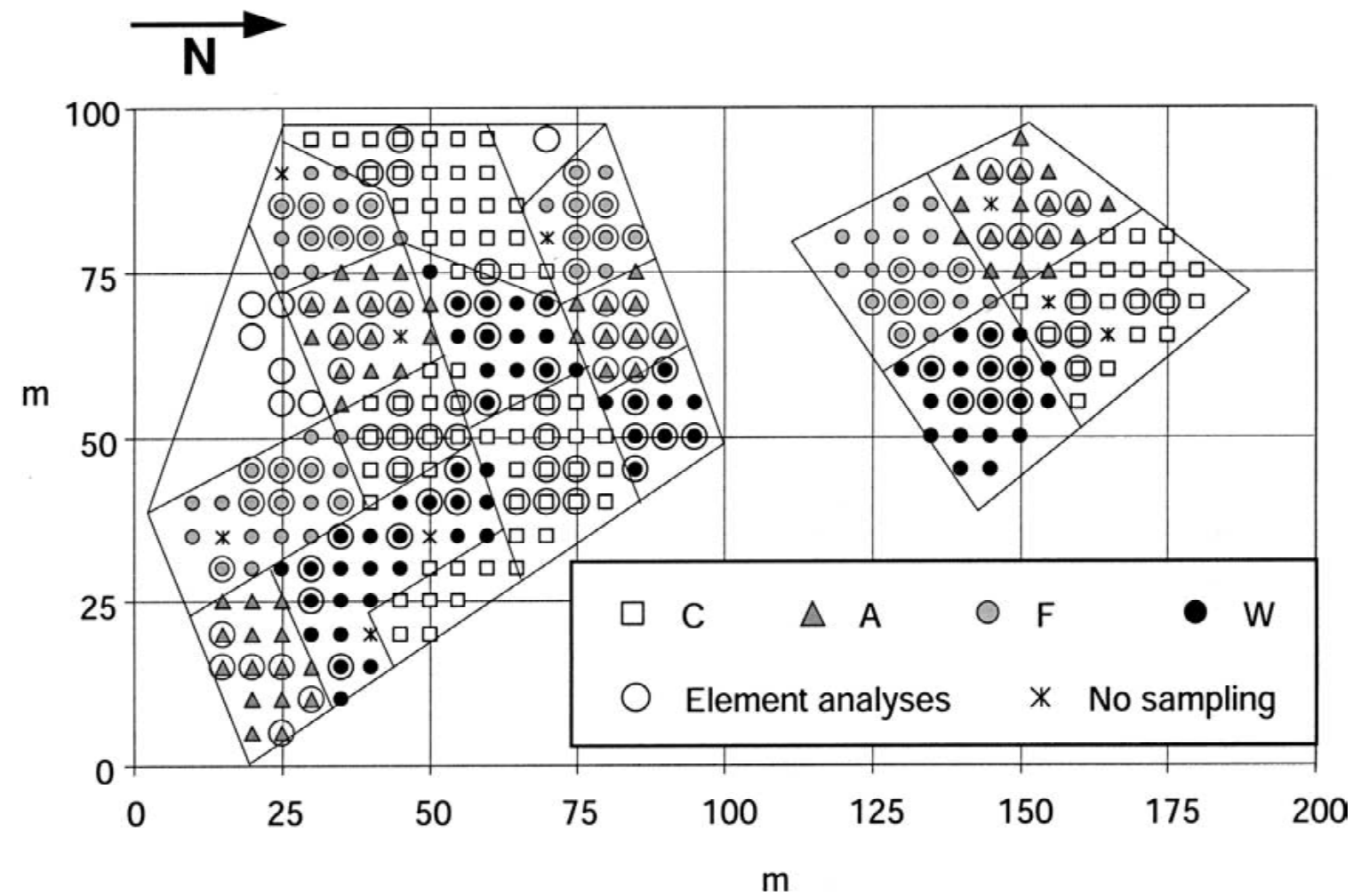

Figure 1. Sampling design on a $5 \times 5$-m grid and assigned treatments: $\mathrm{C}$ - control; $\mathrm{W}-$ water; F - liquid fertiliser; A - ash plots; encircled sampling positions with element analyses of fine roots.

Table 1. Element input $\left(\mathrm{kg} \mathrm{ha}^{-1}\right.$ year $\left.^{-1}\right)$ by the treatments: A - wood ash; F - fertiliser; W - water; C control; n.d. - not determined

\begin{tabular}{|c|c|c|c|c|c|}
\hline \multirow[t]{2}{*}{ Elements } & \multirow[t]{2}{*}{ C } & \multirow[t]{2}{*}{ A } & \multicolumn{2}{|r|}{$\mathrm{F}$} & \multirow[t]{2}{*}{$\mathrm{W}^{\mathrm{a}}$} \\
\hline & & & 1998 & 1999 & \\
\hline $\mathrm{N}$ & 0 & $<0.01$ & 77 & 100 & 7 \\
\hline $\mathrm{S}$ & 0 & 26 & 17 & 18 & 12 \\
\hline $\mathrm{P}$ & 0 & 63 & 13 & 17 & 0.1 \\
\hline $\mathrm{Ca}$ & 0 & 1140 & 183 & 184 & 182 \\
\hline $\mathrm{K}$ & 0 & 232 & 64 & 85 & 3 \\
\hline $\mathrm{Mg}$ & 0 & 76 & 33 & 35 & 25 \\
\hline $\mathrm{Fe}$ & 0 & 20 & 0.2 & 0.3 & 0.2 \\
\hline $\mathrm{Mn}$ & 0 & 19 & 0.07 & 0.08 & 0.03 \\
\hline $\mathrm{Zn}$ & 0 & 0.7 & $<0.01^{\mathrm{b}}$ & $<0.01^{\mathrm{b}}$ & n.d. \\
\hline $\mathrm{Al}$ & 0 & 23 & $<0.03$ & $<0.03$ & $<0.03$ \\
\hline $\mathrm{Cu}$ & 0 & 0.5 & $<0.01^{\mathrm{b}}$ & $<0.01^{\mathrm{b}}$ & n.d. \\
\hline $\mathrm{Cd}$ & 0 & 0.02 & n.d. & n.d. & n.d. \\
\hline
\end{tabular}

${ }^{\mathrm{a}}$ Import of the stream water extrapolated with element concentrations of the water.

${ }^{\mathrm{b}}$ Estimated input of stream water negligible. at $60{ }^{\circ} \mathrm{C}$ for at least 3 days and weighed (separated by horizon).

Needles were sampled in winter (December, January) of 1997/98 and 1999/2000 from 136 selected spruce trees within the experimental site. Trees were located at a minimum distance of $4 \mathrm{~m}$ to the neighbouring-treatment plot. One hundred medial needles were taken from a shoot from the uppermost whorl of the sample tree. Needle samples were dried at $65^{\circ} \mathrm{C}$ until constant weight.

\section{Analyses}

The analyses of soil $\mathrm{pH}$ in a $0.01 M \mathrm{CaCl}_{2}$ extract (Brunner et al., 1999) and fine root biomass (dry weight, DW) was conducted for each of the 257 sample points. The fine root material of 110 selected samples from the Ah horizon (Figure 1) and the needle samples of the 136 trees were ground with a mill (Retsch MM2000) for further analyses. Total C and total $\mathrm{N}$ were measured with a $\mathrm{CN}$ auto-analyser (N2500, Carlo Erba Instruments). Other elements were measured after digestion of the ground material 
in a high pressure microwave (Milestone MLS U1traclave) by ICP-AES (Optima 3000, Perkin-Elmer).

\section{Ingrowth-cores}

To study the root growth dynamics, three trees per plot and three plots per treatment were selected, resulting in a total of 36 sample trees. These trees were mainly located in the centre of the plots. At each sample tree, nine 'ingrowth-cores' were installed in May 1998. First, the soil was taken out with a soil corer (diameter $55 \mathrm{~mm}$ ) to about $100 \mathrm{~mm}$ depth, divided by horizons and sieved. A net-cylinder of glass fibre $(110 \mathrm{~mm}$ height, $50 \mathrm{~mm}$ diameter, $5 \mathrm{~mm}$ mashes) was installed into the hole, before the root-free soil was replaced, horizon by horizon in the hole. The minimum distance between two cores was $100 \mathrm{~mm}$, and the distance from the sample tree was $1.0-1.5 \mathrm{~m}$.

\section{Harvest of ingrowth-cores}

The ingrowth-cores were harvested in March 1999, October 1999 and March 2000, approximately 1, 1.5, or 2 years after installation. At each sampling event three ingrowth-cores per tree were harvested using a large soil corer (diameter $85 \mathrm{~mm}$ ). The soil cores were taken to the lab in plastic bags and stored at $4{ }^{\circ} \mathrm{C}$ for a maximum of 3 days until analysis. With a sharp knife the roots and soil were cut off the net-cylinder. The soil depth was measured and the cylinder was opened with the aid of scissors. Horizons were not analysed separately, because after the first harvest it was observed that the original horizons had been disturbed by the installation procedure. Roots of Norway spruce were washed out, scanned and the architecture was analysed with the Winrhizo ${ }^{\circledR}$ software (Regent Instruments Inc.). Afterwards the roots were dried $\left(60^{\circ} \mathrm{C}, 3\right.$ days) and the biomass was determined.

\section{Turnover}

Root turnover was calculated according to a modified equation in Gill and Jackson (2000):

$$
\text { Root turnover }=\frac{\text { Annual belowground production }}{\text { Mean belowground standing crop. }}
$$

The turnover was calculated as the quotient from the production of fine roots per year as measured by the ingrowth-core after 2 years, and related to the mean standing biomass of fine roots, estimated from the grid sampling results averaged over the 3 years.

\section{Statistics}

Statistical analyses were performed as provided by Statview 5.0 (SAS Inc., Cary). To analyse differences in soil $\mathrm{pH}$ and the fine root biomass in grid-samples, a repeated-measurement ANOVA and a Fisher's PLSD post-hoc test were performed within one treatment on the differences between the years. The changes in element concentrations were analysed on differences between the treatments by a one-way ANOVA at a 5\% probability level. The ingrowth-core data were analysed with a one-way ANOVA on treatment effects at a $5 \%$ probability level, within one harvest. Furthermore, a two-way ANOVA on treatment and time was conducted to reveal differences between the three harvesting events. For the parameters concerning the growth pattern (tips, length, forks, diameter), samples without fine roots were not considered.

\section{Results}

Biomass, growth dynamic and soil pH

The fine root biomass as monitored by the soil coring was not affected by the treatments when considering Ah and B horizon separately (Table 2). However, if data were related to both horizons, there was a significant difference in fine root density between the harvesting events in samples of $\mathrm{C}$ and $\mathrm{A}$ treated plots (Table 2). In the soil of the A plots a significantly higher root density was observed after 2 years. The root density in the soil of C plots was in the year 2000 higher than in the year 1998. A generally increasing root density was observed within the 2 years, irrespective of the treatments (Table 2). The mean annual turnover of fine roots was not affected by the treatments (Table 2, lower part) and ranged from 0.6 to 1.0 year $^{-1}$.

One year after installation the ingrowth-cores revealed a higher proportion of fine root biomass in the cores of the A plots than in the cores of the $\mathrm{W}$ plots (Figure 2). The biomass of fine roots in the cores at the second or third harvest, after 1.5 and 2 years, did not differ between the treatments. The root growth pattern was affected by the treatments. Taking all single differences into account (Figure 2), the $\mathrm{W}$ treatment seemed to reduce the number of root tips and forks, and reduced the root length. The A treatment increased the number of root tips, forks and the root length, but reduced the diameter of the fine roots (Figure 2). 
Table 2. Biomass $\left(\mathrm{kg} \mathrm{m}^{-3}\right)$ and turnover $\left(\right.$ year $\left.^{-1}\right)$ of fine roots as presented in various horizons and affected by the treatments. Different letters indicate a significant difference of biomass between the years within one treatment and soil horizon with $p<0.01$. Fine root turnover is given in the lower part and letters indicate differences between the treatments with $p<0.01$

\begin{tabular}{lrrrl}
\hline Year & C & A & F & W \\
\hline Biomass (Ah-horizon, 0-30 mm) & & \\
1998 & $1.15 \mathrm{a}$ & $2.19 \mathrm{a}$ & $1.75 \mathrm{a}$ & $1.26 \mathrm{a}$ \\
1999 & $1.34 \mathrm{a}$ & $1.86 \mathrm{a}$ & $1.61 \mathrm{a}$ & $1.26 \mathrm{a}$ \\
2000 & $1.59 \mathrm{a}$ & $2.51 \mathrm{a}$ & $2.10 \mathrm{a}$ & $1.28 \mathrm{a}$ \\
Biomass (B-horizon, 30-100 mm) & & \\
1998 & $0.19 \mathrm{a}$ & $0.27 \mathrm{a}$ & $0.28 \mathrm{a}$ & $0.22 \mathrm{a}$ \\
1999 & $0.22 \mathrm{a}$ & $0.36 \mathrm{a}$ & $0.30 \mathrm{a}$ & $0.23 \mathrm{a}$ \\
2000 & $0.21 \mathrm{a}$ & $0.35 \mathrm{a}$ & $0.35 \mathrm{a}$ & $0.21 \mathrm{a}$ \\
Biomass (Ah+B horizon, 0-100 mm) & & \\
1998 & $0.38 \mathrm{~b}$ & $0.60 \mathrm{~b}$ & $0.62 \mathrm{a}$ & $0.44 \mathrm{a}$ \\
1999 & $0.47 \mathrm{ab}$ & $0.72 \mathrm{~b}$ & $0.62 \mathrm{a}$ & $0.45 \mathrm{a}$ \\
2000 & $0.52 \mathrm{a}$ & $0.91 \mathrm{a}$ & $0.76 \mathrm{a}$ & $0.53 \mathrm{a}$ \\
Turnover (Ah+B horizon, $0-100 \mathrm{~mm})$ & & \\
$1998-2000$ & $1.04 \mathrm{a}$ & $0.67 \mathrm{a}$ & $0.66 \mathrm{a}$ & $0.59 \mathrm{a}$ \\
\hline
\end{tabular}

Results depended also on the harvest time. A twoway ANOVA revealed a lower fine root biomass in the ingrowth-cores after 1 year than after 1.5 years. After 2 years the biomass was comparable to that after 1.5 years. The diameter of the roots was larger at the last harvest, after 2 years, than at the harvest after 1.5 years. After 1.5 years the roots had a higher density in forks, more tips and a higher length than in both harvests after 1 or after 2 years.

When the $\mathrm{pH}$ of the soil (Ah horizon) was considered at the same sample points from which the fine roots of the element analysis derived, an elevated $\mathrm{pH}$ in the plots of all three treatments was observed in both years. While the change in $\mathrm{pH}$ in the soil of $\mathrm{F}$ and $\mathrm{W}$ treated plots was in a similar range, the $\mathrm{pH}$ of the A-treated plots made a large shift of about 1.5 units after 2 years of treatment (Figure 3). In general (results of all sample locations) the $\mathrm{pH}$ in the Ah horizon of the soil was increased by A, F, and W after the first and even more after the second growing season (Table 3). In the mineral soil of the $\mathrm{B}$ horizon the $\mathrm{pH}$ shift was less pronounced and was significant in the three treatments only after the second year (Table 3 ).

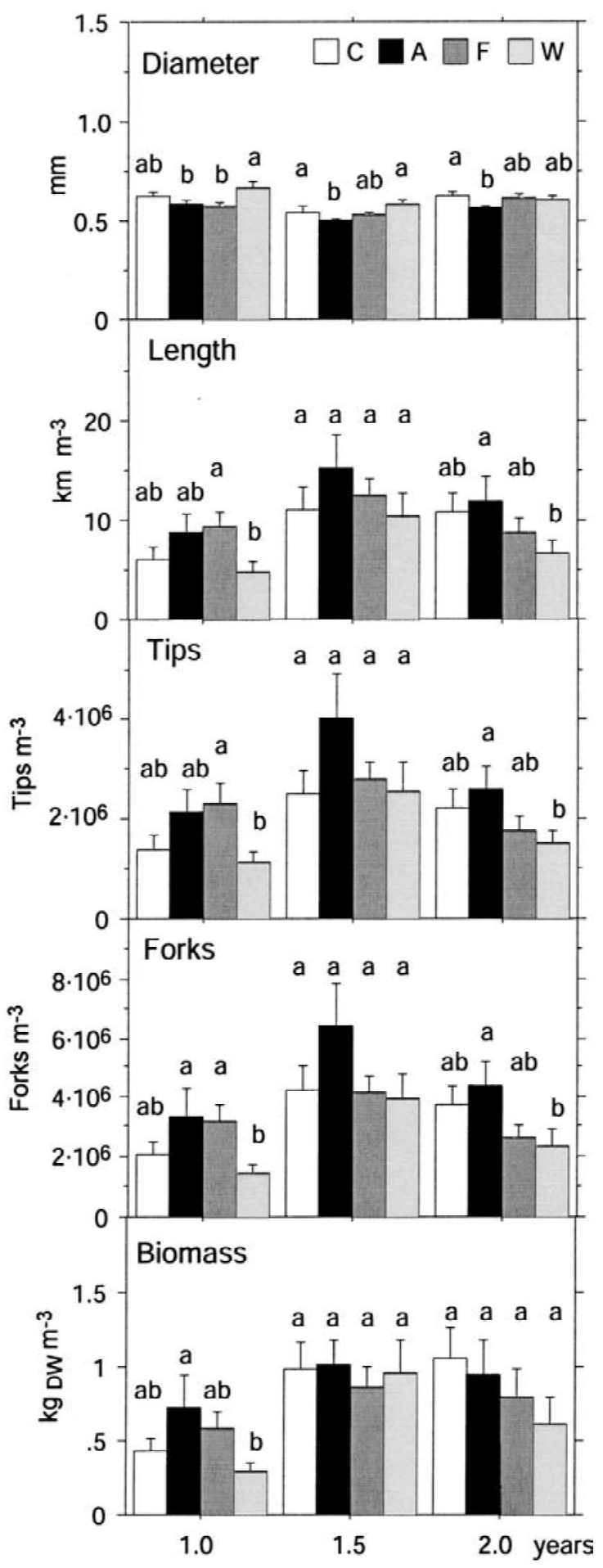

Figure 2. Biomass given as fine root density $\left(\mathrm{kg} \mathrm{DW} \mathrm{m}^{-3}\right)$, amount of forks, tips, length $(\mathrm{km})$ per $\mathrm{m}^{3}$ soil and fine root diameter $(\mathrm{mm})$ of the ingrowth-cores samples, columns represent means \pm SE of the respective parameter $(n=27)$. Different letters indicate a significant difference with $p<0.05$ according to a one-way ANOVA on the factor treatment within one harvest. 

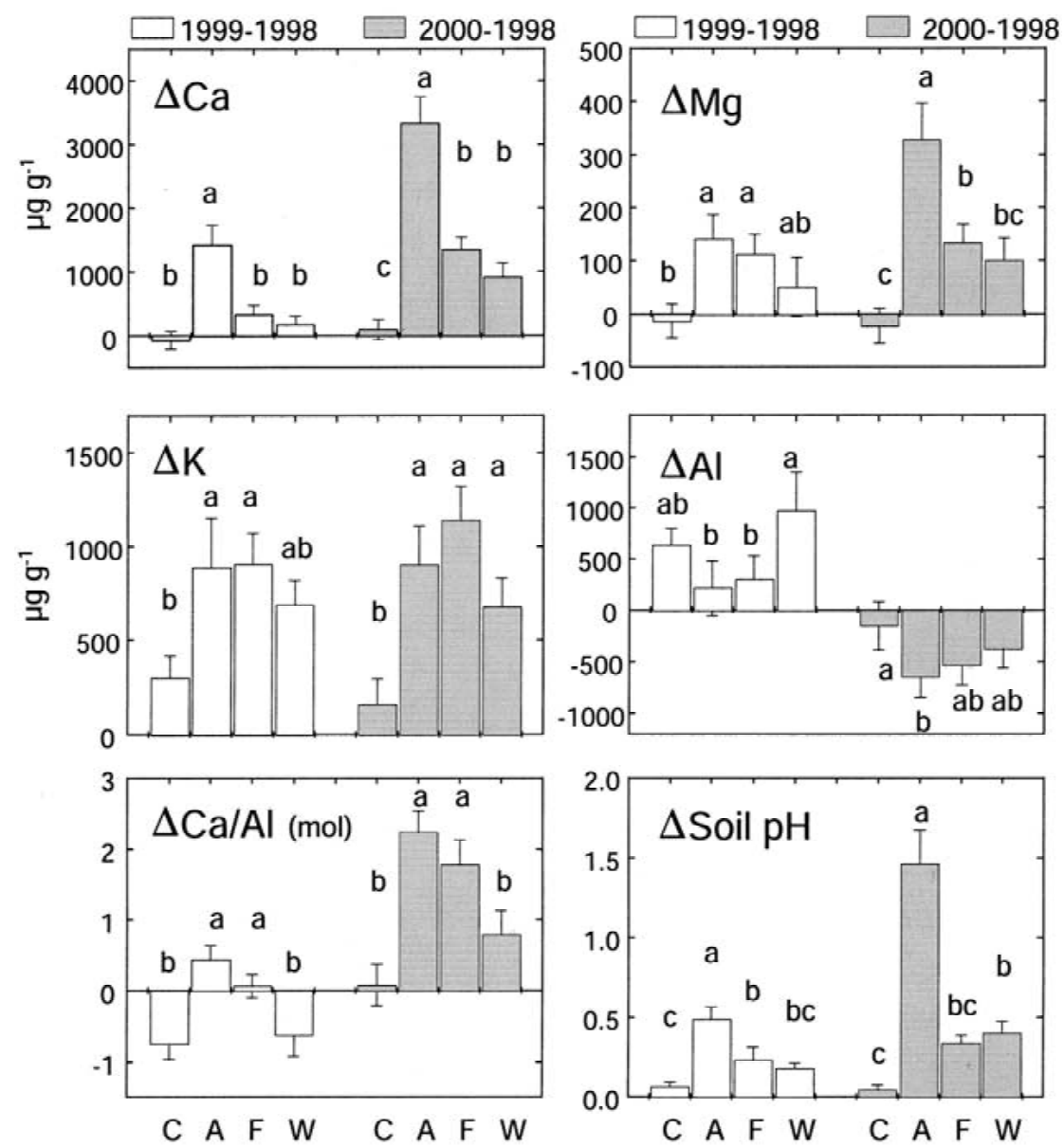

Figure 3. Changes in $\mathrm{Ca}, \mathrm{Mg}, \mathrm{K}, \mathrm{Al}$ concentrations, in the molar $\mathrm{Ca} / \mathrm{Al}$ ratio in the fine roots, and in the soil $\mathrm{pH}$ after 1 and after 2 years of treatments, columns represent a mean $\pm \mathrm{SE}(n=25-31)$ : $\mathrm{C}$ - control; $\mathrm{W}$ - water; $\mathrm{F}$ - liquid fertiliser; $\mathrm{A}$ - ash. Different letters indicate a significant difference with $p<0.05$ according to a one-way ANOVA on the factor treatment concerning the differences of a harvest from the concentrations measured before treatments started (1998).

Table 3. Soil $\mathrm{pH}$ in the soil core samples. Different letters indicate a significant difference between the years within one treatment and soil horizon with $p<0.01$

\begin{tabular}{ccccc}
\hline Year & $\mathrm{C}$ & $\mathrm{A}$ & $\mathrm{F}$ & $\mathrm{W}$ \\
\hline $\mathrm{pH}$ (Ah-horizon, 0-30 mm) & & \\
1998 & $3.28 \mathrm{a}$ & $3.26 \mathrm{c}$ & $3.25 \mathrm{c}$ & $3.34 \mathrm{~b}$ \\
1999 & $3.30 \mathrm{a}$ & $3.70 \mathrm{~b}$ & $3.38 \mathrm{~b}$ & $3.45 \mathrm{~b}$ \\
2000 & $3.35 \mathrm{a}$ & $4.63 \mathrm{a}$ & $3.50 \mathrm{a}$ & $3.66 \mathrm{a}$ \\
$\mathrm{pH}($ B-horizon, 30-100 mm) & & \\
1998 & $3.46 \mathrm{a}$ & $3.47 \mathrm{~b}$ & $3.45 \mathrm{~b}$ & $3.50 \mathrm{~b}$ \\
1999 & $3.49 \mathrm{a}$ & $3.51 \mathrm{~b}$ & $3.46 \mathrm{ab}$ & $3.51 \mathrm{~b}$ \\
2000 & $3.50 \mathrm{a}$ & $3.67 \mathrm{a}$ & $3.51 \mathrm{a}$ & $3.55 \mathrm{a}$ \\
\hline
\end{tabular}

\section{Elements in the fine roots}

No differences (one-way ANOVA, $p<0.01$ ) in the fine root elements were detected between the designated plots in the samples of 1998, before the treatments started (data not shown). Within the 2 years of treatment $\mathrm{Ca}, \mathrm{Mg}, \mathrm{K}$, and $\mathrm{P}$ concentrations in the fine roots of Norway spruce were improved by the A as well as by the F treatment (Figures 3 and 4) compared to the $\mathrm{C}$. The $\mathrm{W}$ treatment also had a significant effect on the changing of the $\mathrm{K}$ and $\mathrm{Ca}$ concentrations after 2 years of treatment years. The $\mathrm{Al}, \mathrm{Fe}$, and $\mathrm{Mn}$ concentrations were decreased in the $\mathrm{A}$ and $\mathrm{F}$ treated roots compared to the $\mathrm{C}$ and $\mathrm{W}$ treatments (Figures 3 and 4). Thus, the molar $\mathrm{Ca} / \mathrm{Al}$ ratio was significantly enhanced by the A and F treatments (Figure 3). The $\mathrm{S}$ and $\mathrm{Zn}$ concentrations were not dependent on the 
treatment applied (Figure 4), although these elements showed differences between the years. The $\mathrm{N}$ concentration of the roots was only significantly changed by the $\mathrm{F}$ treatment after 1 year. After 2 years the increase in the $\mathrm{N}$ concentration in the roots of $\mathrm{F}$ treatment was significantly different from the change with the A treatment, where the concentration decreased (Figure 4). The changes in the $C$ concentration after the second growing season differed between the A treatment, where $\mathrm{C}$ tended to decrease, and the $\mathrm{W}$ and $\mathrm{C}$ treatments, where the $\mathrm{C}$ concentration increased. The $\mathrm{C} / \mathrm{N}$ ratio in the fine roots was decreased by the $\mathrm{F}$ treatment, while the A treatment seemed to have a slight positive effect after 2 years (Figure 4 ).

Mean $\mathrm{Cu}$ concentrations in the fine roots were in the range of 9.0-10.4 $\mu \mathrm{g} \mathrm{g}^{-1}$ (data not shown). The majority of $\mathrm{Cd}$ concentrations measured was below the detection limit of $1.5 \mu \mathrm{g} \mathrm{g}^{-1}$. An accumulation, that means increased concentrations in the fine roots due to the A treatment, of heavy metals such as $\mathrm{Cu}, \mathrm{Cd}$ (data not shown), and Zn (Figure 4) was not observed in the roots after 2 years with a total wood ash input of 8000 $\mathrm{kg} \mathrm{ha}^{-1}$.

\section{Elements in needles}

Within 2 years an increase of the $\mathrm{N}$ and $\mathrm{P}$ concentrations in the current needles was observed under the $\mathrm{F}$ treatment. The $\mathrm{N}$ concentrations in the needles were in general higher in the 2000 than in the 1998 samples, before treatments (Table 4). $\mathrm{Mg}, \mathrm{Ca}, \mathrm{S}$, and $\mathrm{Al}$ concentrations were not significantly changed in the current foliage. $\mathrm{K}$ concentrations were increased by the $\mathrm{A}$ and $\mathrm{F}$ treatments but also in the control plots. The Mn concentrations decreased in the $\mathrm{C}$ and $\mathrm{W}$ treatments, while $\mathrm{Zn}$ was increased in the foliage of the $\mathrm{A}$ and $\mathrm{F}$ treated trees. Fe concentrations were increased irrespective of the treatment (Table 4).

\section{Discussion}

\section{Root growth}

The root biomass in the topsoil was not affected by the treatments during the observation period. However, a significantly higher root density was observed in the $\mathrm{C}$ and A plots, and there only after 2 years of treatments. The fine root density was already different among the plots designated to the treatments before the experiment started in spring 1998. In a similar experiment in
Sweden wood ash application led to a decrease in fine root biomass in the topsoil (Clemensson-Lindell and Persson, 1995). In an experiment in Germany the fine root biomass was strongly enhanced by a high input of $\mathrm{Mg}$ in a spruce forest within three growing seasons, while a combined $\mathrm{K}$ and $\mathrm{Mg}$ fertilisation showed no growth effects (Raspe et al., 1994).

Production of fine roots as estimated from ingrowth-core data showed a high variation, which is comparable to the variation in other earlier studies (e.g., Persson et al., 1998). Laboratory experiments have shown that high $\mathrm{N}$ supply could lead to reduced root growth (George et al., 1999) and also to increased root growth (George and Marschner, 1996). In the present study, the F treatment contained $70-100 \mathrm{~kg}$ $\mathrm{N} \mathrm{ha}{ }^{-1}$ year $^{-1}$, yet a change in relative root growth was not observed. In comparison, Magill et al. (2000) did not observe an influence on fine root biomass after several years of $\mathrm{N}$ addition in a pine or a hardwood stand, but a change in storage $\mathrm{N}$ due to enhanced $\mathrm{N}$ concentrations in the fine roots (Magill et al., 2000).

The two growing seasons observed were a short period in the time scale of trees. Stober et al. (2000) reported significant differences in fertilised against unfertilised ingrowth-cores within two growing seasons in various spruce forests, while after only one growing season no effects had been observed. As early as half a year after installation Raich et al. (1994) observed differences between $\mathrm{N}$ fertilised ingrowth-cores and the remaining cores. In the present study the higher proportion of roots grown in the cores after 1 year under the $\mathrm{F}$ and $\mathrm{A}$ treatment was probably attributed to the fine roots foraging for nutrients. Although the initial growth dynamics were influenced by the $\mathrm{A}$ and $\mathrm{F}$ treatments, the final fine root density was not affected by the treatments.

Persson et al. (1998) observed a stabilisation of growth with exclusion of $\mathrm{N}$ and $\mathrm{S}$, the main contributors to soil acidification, by a roof. The roots grew stouter and shorter, which the authors concluded to be a sign of higher root vitality and enhanced mycorrhization. In contrast, in the present study the A treatment resulted in longer and thinner roots and more branches. Another experiment in a Norway spruce forest in Sweden also reported increased length of fine roots with wood ash application (Clemensson-Lindell and Persson, 1995). Thus, the change to a greater branching intensity and length in root growth could have been caused by improved soil $\mathrm{pH}$ and nutrient availability. The fine root turnover observed in the present study was within the range of temperate coni- 

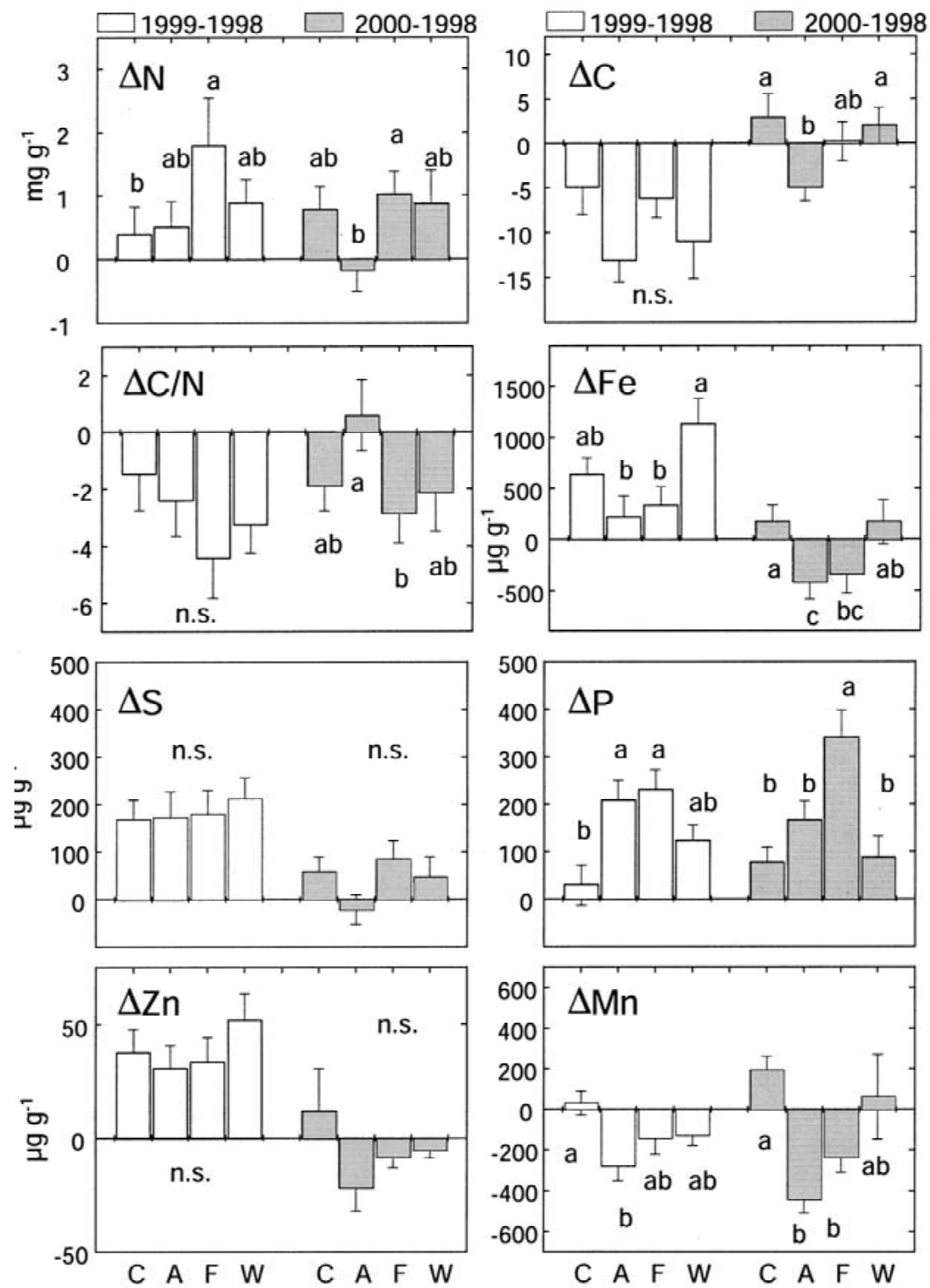

Figure 4. Changes in N, C, Fe, S, P, Zn, Mn concentrations and in the C/N ratio in the fine roots after 1 and after 2 years of treatments, columns represent a mean $\pm \mathrm{SE}(n=25-31)$ : C - control; W - water; F-liquid fertiliser; $\mathrm{A}$ - ash. Different letters indicate a significant difference with $p<0.05$ according to a one-way ANOVA on the factor treatment concerning the differences of a harvest from the concentrations measured before treatments started (1998).

ferous forests as described by Gill and Jackson (2000). Strubelt et al. (1998) using a similar method obtained a turnover of $0.4-1.3$ year $^{-1}$ with Pinus in Germany, which is comparable to our results.

\section{Elements}

The elements in the fine roots of the present study were in the range of reported values for other European study sites (Table 5). The $\mathrm{N}$ concentration was moderate compared to high values reported from Germany and France and low values in Sweden. The $\mathrm{Ca}$, $\mathrm{Mg}$, and $\mathrm{K}$ concentrations in the roots were high compared to results from Germany, France, and Sweden. In the present study $\mathrm{N}$ was enhanced in the fine roots only by the $\mathrm{F}$ treatment. The fine roots might be a significant sink for added $\mathrm{N}$ as has been observed earlier: Magill et al. (1997) calculated that about $15 \%$ of the 
Table 4. Element concentrations ( $\left.\mathrm{mg} \mathrm{g}^{-1} \mathrm{DW}\right)$ in the current needles before the treatments and after 2 years of treatment (harvest in autumn of the previous year): ns - not significantly different, ${ }^{*},{ }^{* *},{ }^{* * *}$ difference with $p<0.05$, $p<0.01, p<0.001$, respectively

\begin{tabular}{|c|c|c|c|c|c|c|c|c|c|}
\hline \multirow[t]{2}{*}{ Elements } & \multicolumn{2}{|r|}{$\mathrm{C}$} & \multicolumn{2}{|r|}{ A } & \multicolumn{2}{|r|}{$\mathrm{F}$} & \multicolumn{2}{|r|}{$\mathrm{W}$} & \multirow[t]{2}{*}{ Suff. range ${ }^{a}$} \\
\hline & 1998 & 2000 & 1998 & 2000 & 1998 & 2000 & 1998 & 2000 & \\
\hline $\mathrm{N}$ & 15.1 & $15.9^{*}$ & 14.9 & $15.7^{*}$ & 14.4 & $15.8^{* * *}$ & 14.8 & $15.3^{\mathrm{ns}}$ & $13.5-17.0$ \\
\hline $\mathrm{S}$ & 0.93 & $0.88^{\mathrm{ns}}$ & 0.92 & $0.96^{\mathrm{ns}}$ & 0.93 & $0.96^{\mathrm{ns}}$ & 0.90 & $0.88^{\mathrm{ns}}$ & No data \\
\hline $\mathrm{P}$ & 1.40 & $1.32^{\mathrm{ns}}$ & 1.38 & $1.43^{\mathrm{ns}}$ & 1.31 & $1.42^{*}$ & 1.33 & $1.31^{\mathrm{ns}}$ & $1.3-2.5$ \\
\hline $\mathrm{Ca}$ & 4.60 & $4.14^{\mathrm{ns}}$ & 4.54 & $4.47^{\mathrm{ns}}$ & 5.33 & $5.29^{\mathrm{ns}}$ & 4.44 & $3.89^{\mathrm{ns}}$ & $3.5-8.0$ \\
\hline K & 3.37 & $4.00^{* *}$ & 3.68 & $5.10^{* * *}$ & 3.37 & $4.78^{* * *}$ & 3.69 & $3.81^{\mathrm{ns}}$ & $5.0-12.0$ \\
\hline $\mathrm{Mg}$ & 0.92 & $0.94^{\mathrm{ns}}$ & 0.94 & $1.05^{\mathrm{ns}}$ & 1.02 & $1.07^{\mathrm{ns}}$ & 0.89 & $0.89^{\mathrm{ns}}$ & $1.0-2.5$ \\
\hline $\mathrm{Fe}$ & 0.038 & $0.042^{* *}$ & 0.039 & $0.046^{* * *}$ & 0.038 & $0.049^{* * *}$ & 0.035 & $0.043^{* * *}$ & No data \\
\hline Mn & 1.96 & $1.66^{* * *}$ & 1.85 & $1.72^{\mathrm{ns}}$ & 2.21 & $2.08^{\mathrm{ns}}$ & 2.16 & $1.83^{* *}$ & $0.05-0.5$ \\
\hline $\mathrm{Zn}$ & 0.016 & $0.018^{\mathrm{ns}}$ & 0.017 & $0.024^{* *}$ & 0.021 & $0.026^{* * *}$ & 0.019 & $0.018^{\mathrm{ns}}$ & $0.015-0.06$ \\
\hline $\mathrm{Al}$ & 0.08 & $0.07^{\mathrm{ns}}$ & 0.08 & $0.08^{\mathrm{ns}}$ & 0.08 & $0.09^{\mathrm{ns}}$ & 0.07 & $0.07^{\mathrm{ns}}$ & No data \\
\hline
\end{tabular}

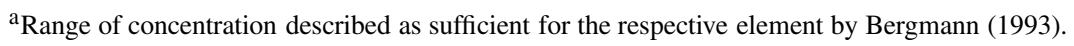

$\mathrm{N}$ applied over 6 years was retained through a change in root storage $\mathrm{N}$ in red pine. The observation that $\mathrm{N}$ addition led to higher $\mathrm{N}$ concentrations in spruce fine roots was confirmed, among others, by Stober et al. (2000). Hahn and Marschner (1998b) investigated the element concentrations in fine roots of Norway spruce under acid irrigation and liming. On the acid irrigated plot $\mathrm{Ca}$ and $\mathrm{Mg}$ in the roots decreased, but 2 years after the end of irrigation no difference was found. Liming increased root concentrations of $\mathrm{Ca}$ and $\mathrm{Mg}$, and reduced Mn and Al (Hahn and Marschner, 1998b). The results of liming were similar to the wood ash effects observed in the present study. In a field experiment on the effect of the alkalising compounds wood ash and lime on the fine roots of spruce, $\mathrm{Ca}, \mathrm{Ca} / \mathrm{Al}$ ratio, $\mathrm{Mg}, \mathrm{P}$, and $\mathrm{K}$ were enhanced in the roots (Persson and Ahlström, 1994), comparable with the results in the present study. In contrast to our results, the concentrations of $\mathrm{Mn}$ increased 2 years after ash application, while we observed decreasing concentrations in the roots.

Considering the critical molar $\mathrm{Ca} / \mathrm{Al}$ ratio for $\mathrm{Al}$ stress in the fine roots of 0.2 (Cronan and Grigal, 1995), however, the roots in the present study, which had a molar $\mathrm{Ca} / \mathrm{Al}$ ratio of about 1.5 (data not shown) before the treatments, were far from being under $\mathrm{Al}$ stress. This was also due to the comparably high $\mathrm{Ca}$ concentrations in the fine roots and needles, and, therefore, an assumedly good Ca supply in Swiss forests (Tables 4 and 5, Brunner et al., 2002; Landolt, 1997).
Hüttl (1990) described long lasting improvement in $\mathrm{Mg}$ and $\mathrm{K}$ nutrition through a balanced fertilisation. In contrast, Ohno and Erich (1990) observed a decreasing relative availability of $\mathrm{Mg}$ and $\mathrm{K}$ through wood ash additions. Their finding that $\mathrm{Ca}$ was the most available nutrient after wood ash application (Ohno and Erich, 1990) agreed with the present results obtained with fine roots. Furthermore, the changes observed with the A treatment in the fine roots matched with the results observed in the upper soil after wood ash application in the USA (Kahl et al., 1996), where the availability of $\mathrm{Mn}$ and $\mathrm{Al}$ was decreased, while the $\mathrm{Ca}, \mathrm{K}$ and $\mathrm{Mg}$ availability in the top soil and the soil $\mathrm{pH}$ increased.

\section{Fine root versus needle elements}

All elements measured in the needles were within the 'typical' range of Norway spruce needle elements in Switzerland (Landolt et al., 1989). In comparison to a European survey (Stefan et al., 1997), N and Mn concentrations were in the upper third, while $\mathrm{K}, \mathrm{S}$, $\mathrm{Mg}$, and $\mathrm{Zn}$ concentrations were in the lower third of the European range (Stefan et al., 1997). This observation is confirmed by comparison with general knowledge about plant nutrition (Bergmann, 1993): $\mathrm{P}$, $\mathrm{Mg}, \mathrm{Zn}$, and $\mathrm{K}$ were close to the lower limit, whereas other nutrients were basically in the range of 'sufficient' supply (Bergmann, 1993). Mn was measured in high concentrations compared to the range defined as 'sufficient'. However, the Mn concentrations in the shoot are quite variable, and especially with a low 
Table 5. Element concentrations ( $\mathrm{mg} \mathrm{g}^{-1} \mathrm{DW}$ ) in fine roots of Norway spruce of Unterehrendingen compared to results from other Swiss and European Norway spruce forest stands: n.d. - not determined

\begin{tabular}{|c|c|c|c|c|c|c|c|}
\hline & Unterehrendingen & Alptal $^{\mathrm{a}}$ & Beatenberg $^{\mathrm{a}}$ & Chironico $^{a}$ & \multirow{2}{*}{$\frac{\text { Waldstein }^{\mathrm{b}}}{\text { Germany }}$} & \multirow{2}{*}{$\frac{\text { Aubure }^{\mathrm{b}}}{\text { France }}$} & \multirow{2}{*}{$\frac{\text { Skogaby }^{\mathrm{b}}}{\text { Sweden }}$} \\
\hline & \multicolumn{4}{|c|}{ Switzerland } & & & \\
\hline Age (years) & 70 & 200 & 200 & 160 & 80 & 100 & 30 \\
\hline Elevation (m asl) & 450 & 1160 & 1510 & 1360 & 700 & 1050 & 100 \\
\hline Soil pH (0-100 mm) & 3.3 & 5.4 & 2.9 & 3.7 & 3.5 & 3.7 & 4.0 \\
\hline \multicolumn{8}{|l|}{ Elements (mg g $\left.{ }^{-1} \mathrm{DW}\right)$} \\
\hline $\mathrm{N}$ & 13.9 & 10.1 & 11.6 & 13.9 & 16.9 & 16.2 & 9.7 \\
\hline $\mathrm{S}$ & 0.98 & 0.78 & n.d. & 1.16 & 1.28 & 1.17 & 0.7 \\
\hline $\mathrm{P}$ & 1.18 & 0.65 & n.d. & 0.88 & 1.05 & 1.30 & 0.6 \\
\hline $\mathrm{Ca}$ & 4.13 & 7.96 & 4.31 & 7.13 & 3.40 & 2.94 & 2.2 \\
\hline $\mathrm{K}$ & 3.13 & 3.30 & 2.21 & 3.69 & 0.65 & 0.75 & 0.4 \\
\hline $\mathrm{Mg}$ & 0.76 & 1.05 & 0.78 & 1.33 & 0.40 & 0.41 & 0.5 \\
\hline $\mathrm{Fe}$ & 1.59 & 2.33 & 0.12 & 4.19 & n.d. & n.d. & n.d. \\
\hline Mn & 0.80 & 0.29 & 0.19 & 0.32 & n.d. & n.d. & n.d. \\
\hline $\mathrm{Zn}$ & 0.08 & 0.10 & 0.13 & 0.38 & n.d. & n.d. & n.d. \\
\hline $\mathrm{Al}$ & 2.03 & 2.81 & 0.20 & 5.78 & n.d. & n.d. & n.d. \\
\hline
\end{tabular}

${ }^{a}$ Data from LWF for Alptal, Beatenberg and Chironico according to Brunner et al. (2002).

${ }^{\mathrm{b}}$ Data from NYPHIS/CANIF for Aubure, Waldstein, Skogaby according to Bauer et al. (2000).

soil $\mathrm{pH}$, high $\mathrm{Mn}$ concentrations have been reported (Marschner, 1995).

With a biogeochemical model it was calculated that the fine roots (assuming one turnover a year) contribute one-third of the global annual net primary production (Jackson et al., 1997) and thus play an important role, not only in the tree physiology, but also in the quantitative contribution to the nutrient budget of a tree. Foliage analyses have been used for a long time to estimated the nutritional status of a tree or a whole forest, but in some aspects the element concentration of the foliage might be misleading. For example heavy metals are immobilised very rapidly and mostly enriched in the roots and not transported to the shoots, as known from laboratory evidence (e.g., Stienen and Bauch, 1988). Also nutritional elements of low mobility, such as Ca might be underestimated if analysed only in the foliage. Changes in the soil should logically be reflected earlier in the roots than in the shoots, and this was confirmed by the present study. While a significant influence of the applied wood ash on the $\mathrm{Ca}$ concentrations in the fine roots was observed, no such effect was evident in the current needles. In contrast to its low concentration in the cytosol, Ca has elementary functions in the plant metabolism (Reddy, 2001). Low amounts of $\mathrm{Ca}$ are sufficient to preclude deficiency and a surplus of $\mathrm{Ca}$ can be detoxified in the apoplast or as Ca-oxalate in the needles (Gülpen et al., 1995). Like $\mathrm{Ca}$, most of the $\mathrm{Al}$ supplied to a Norway spruce root is immobilised in the root apoplast (Marschner, 1995; Heim et al., 1999), therefore molar $\mathrm{Ca} / \mathrm{Al}$ ratios in roots might give a more reliable estimate of a potential $\mathrm{Al}$ stress than in the shoots. In addition, the concentrations of $\mathrm{Mg}$ were also enhanced in the roots, but not in the needles. $\mathrm{Mg}$ has been shown to be more critical than Ca in forest nutrition (Hüttl, 1990), because $\mathrm{Mg}$ becomes easily limited on $\mathrm{Mg}$ poor soils.

The change in soil $\mathrm{pH}$ had a direct influence on the nutrient availability in the soil. For example, the decrease in Mn concentration in the fine roots is a consequence of a decreased availability of $\mathrm{Mn}$ to the roots because of an increased $\mathrm{pH}$ with the $\mathrm{A}$ and $\mathrm{F}$ treatments (Marschner, 1995). Thus, our results support the evaluation of Bakker (1999) that fine root nutrients are suitable indicators of forest nutrition, but should be supported by certain soil parameters.

\section{Concluding remarks}

The application of wood ash or of a fertilisation, as observed in this study on the fine roots of Norway spruce, was appropriate to mitigate acidification and its consequences, such as deficiency in, e.g., K, P, and $\mathrm{Mg}$. Thus, the recycling of wood ash to the forest is confirmed as a suitable method in the short-term view, always bearing in mind certain prerequisites for the quality and amount of the wood ash (Kahl et al., 1996). 
Although no accumulation of heavy metals in the fine roots was observed in the present study, in the longterm view mobilisation of heavy metals could occur (Zhan et al., 1996). Therefore, heavy metal concentrations in the wood ash should be kept as low as possible by the use of uncontaminated wood and a technically sound combustion. A long-term evaluation of all aspects, from the effects on the soil biology to the effects on the tree growth, is essential with respect to the sustainability of the fertilisations.

In analogue to their physiological position, the fine roots as indicators of the nutritional status of a forest soil can be assumed to be, from a temporal point of view, mediators between the soil, which reflects the current status on the one hand and the foliage, which integrates over a long period of time on the other hand. The results confirm that fine root data can complement soil and foliar indicators in evaluating site conditions. Thus, it would be worthwhile to include parameters based on fine roots in monitoring programs such as the UN/ECE-ICP forest (ICP, 1998).

\section{Acknowledgements}

We thank S. Brodbeck and R. Köchli for skilful work in the laboratory and field. Furthermore we are grateful to P. Bleuler for maintaining the experimental setup in the field. We are grateful to the laboratory team of the 'Soil Ecology' group and the central laboratory for the sampling, handling and analyses of the sample data. We thank M. Sieber for linguistic improvement of the English. We thank the village and the forestry service of Unterehrendingen, who kindly allowed us to perform the study in their district. The project was funded by the Swiss Federal Office for Education and Science (BBW) and the Swiss Agency for the Environment, Forests and Landscape (BUWAL) as part of the COST E6 Eurosilva Project: Forest tree physiology research.

\section{References}

Bakker M R 1999 Fine-root parameters as indicators of sustainability of forest ecosystems. For. Ecol. Manage. 122, 7-16.

Bauer G A, Persson H, Persson T, Mund M, Hein M, Kummetz E, Matteucci H, van Oene H, Scarascia-Mugnozza G and Schulze E D 2000 Linking plant nutrition and ecosystem processes. In Carbon and Nitrogen Cycling in European Forest Ecosystems. Eds. E D Schulze. pp. 63-98. Ecological Studies 142, Springer, Berlin.
Bergmann W 1993 Ernährungsstörungen bei Pflanzen. 3rd edit, Gustav Fischer, Jena. 835 pp.

Bramryd T and Fransman B 1995 Silvicultural use of wood ashes Effects on the nutrient and heavy metal balance in a pine (Pinus sylvestris, L.) forest soil. Wat. Air Soil Pollut. 85, 1039-1044.

Brunner I, Rigling D, Egli S and Blaser P 1999 Response of Norway spruce seedlings in relation to chemical properties of forest soils. For. Ecol. Manage. 116, 71-81.

Brunner I, Brodbeck S and Walthert L 2002 Fine root chemistry, starch concentration, and 'vitality' of subalpine conifer forests in relation to soil pH. For. Ecol. Manage. 165, 75-84.

Bundt M, Widmer F, Pesaro M, Zeyer J and Blaser P 2001 Preferential flow paths: biological 'hot spots' in soils. Soil Biol. Biochem. 33, 729-738

Clarholm M 1998 Wood ash to counteract potential phosphorus and potassium limitations in a Norway spruce forest subjected to air pollution. Scand. J. For. Res. 2, 67-75.

Clemensson-Lindell A and Persson H 1995 Fine-root vitality in a Norway spruce stand subjected to various nutrient supplies. Plant Soil 168/169, 167-172.

Cronan C S and Grigal D F 1995 Use of calcium/aluminum ratios as indicators of stress in forest ecosystems. J. Environ. Qual. 24, 209-226.

Ellenberg H and Klötzli F 1972 Waldgesellschaften und Waldstandorte der Schweiz. Mitteilungen EAFV 42, 587-930.

Eriksson H M 1998 Short-term effects of granulated wood ash on forest soil chemistry in SW and NE Sweden. Scand. J. For. Res. 2, 43-55.

Eriksson H M, Nilsson T and Nordin A 1998 Early effects of lime and hardened and non-hardened ashes on $\mathrm{pH}$ and electrical conductivity of the forest floor, and relations to some ash and lime qualities. Scand. J. For. Res. 2, 56-66.

FAO 1988 FAO-Unesco soil map of the world. 60. Food and Agricultural Organisation of the United Nations, Rome.

Flückiger W and Braun S 1998 Nitrogen deposition in Swiss forests and its possible relevance for leaf nutrient status, parasite attacks and soil acidification. Environ. Pollut. 1, 69-76.

George E and Marschner H 1996 Nutrient and water uptake by roots of forest trees. Z. Pflanzenern. Bodenk. 159, 11-21.

George E, Kircher S, Schwarz P, Tesar A and Seith B 1999 Effect of varied soil nitrogen supply on growth and nutrient uptake of young Norway spruce plants grown in a shaded environment. Z. Pflanzenern. Bodenk. 162, 301-307.

Gill R A and Jackson R B 2000 Global patterns of root turnover for terrestrial ecosystems. New Phytol. 147, 13-31.

Gülpen M, Türk S and Fink S 1995 Ca nutrition of conifers. Z. Pflanzenern. Bodenk. 158, 519-527.

Hahn G and Marschner H 1998a Cation concentrations of short roots of Norway spruce as affected by acid irrigation and liming. Plant Soil 199, 23-27.

Hahn G and Marschner H 1998b Effect of acid irrigation and liming on root growth of Norway spruce. Plant Soil 199, 11-22.

Heim A, Luster J, Brunner I, Frey B and Frossard E 1999 Effects of aluminium treatment on Norway spruce roots: Aluminium binding forms, element distribution, and release of organic substances. Plant Soil 216, 103-116.

Hüttl R F 1990 Nutrient supply and fertilizer experiment in view of N saturation. Plant Soil 128, 45-58.

ICP Forest Manual 1998 UN/ECE Convention on long-range transboundary air pollution. 4th ed., Programme Coordinating Centre, Federal Research Centre for Forestry and Forest Products, Hamburg. 
Ingestad T and Lund A-B 1986 Theory and techniques for steady state mineral nutrition and growth of plants. Scand. J. For. Res. $1,439-453$.

Jackson R B, Mooney H A and Schulze E D 1997 A global budget for fine root biomass, surface area, and nutrient contents. Proc. Natl. Acad. Sci. USA 94, 7362-7366.

Kahl J S, Fernandez I J, Rustad L E and Peckenham J 1996 Threshold application rates of wood ash to an acidic forest soil. J. Environ. Qual. 25, 220-227.

Landolt W 1997 Mangel oder Überschuss. In Forum für Wissen: Säure- und Stickstoffbelastungen - Ein Risiko für den Schweizer Wald? pp. 51-58. WSL, Birmensdorf.

Landolt W, Guecheva M and Bucher J B 1989 The spatial distribution of different elements in and on the foliage of Norway spruce growing in Switzerland. Environ. Pollut. 56, 155-167.

Linder S 1995 Foliar analysis for detecting and correcting nutrient imbalances in Norway spruce. Ecol. Bull. 44, 178-190.

Magill A H, Aber J D, Hendricks J J, Bowden R D, Melillo J M and Steudler P A 1997 Biogeochemical response of forest ecosystems to simulated chronic nitrogen deposition. Ecol. Appl. 7, $402-415$.

Magill A H, Aber J D, Berntson G M, McDowell W H, Nadelhoffer K J, Melillo J M and Steudler P 2000 Long-term nitrogen additions and nitrogen saturation in two temperate forests. Ecosystems 3, 238-253.

Marschner H 1995 Mineral Nutrition of Higher Plants. 2nd edition. Academic Press, London. 889 pp.

Matzner E and Murach D 1995 Soil changes induced by air pollutant and their implication for forests in central Europe. Wat. Air Soil Pollut. 85, 63-76.

Meiwes K J 1995 Application of lime and wood ash to decrease acidification of forest soils. Wat. Air Soil Pollut. 85, 143-152.

Nilsson S I, Andersson S, Valeur I, Persson T, Bergholm J and Wirén A 2001 Influence of dolomite lime on leaching and storage of C, $\mathrm{N}$ and $\mathrm{S}$ in a Spodsol under Norway spruce (Picea abies (L.) Karst.). For. Ecol. Manage. 146, 55-73.

Ohno T and Erich M S 1990 Effect of wood ash application on soil $\mathrm{pH}$ and soil test nutrient levels. Agric. Ecosyst. Environ. 32, 223 239.

Persson H and Ahlström K 1992 The effects of liming on fine-roots in forest ecosystems. In Responses of Forest Ecosystems to Environmental Changes. Eds. A Teller, P Mathy, J N R Jeffers. pp. 827-828. Elsevier, London.

Persson H and Ahlström K 1994 The Effects of alkalizing compounds on fine-root growth in a Norway spruce stand in southwest Sweden. J. Environ. Sci. Health A29, 803-820.

Persson H, Majdi H and Clemensson-Lindell A 1995 Effects of acid deposition on tree roots. Ecol. Bull. 44, 158-167.

Persson H, Ahlstrom K and Clemensson-Lindell A 1998 Nitrogen addition and removal at Gardsjon - effects on fine-root growth and fine-root chemistry. For. Ecol. Manage. 101, 199-205.

Raich J W, Riley R H and Vitousek P M 1994 Use of root-ingrowth cores to assess nutrient limitations in forest ecosystems. Can. J. For. Res. 24, 2135-2138.

Rapp C 1992 Effects of liming and N-fertilization on soil chemistry, biomass and nutrient content of fine roots in a mature beech stand in the Solling area (Germany). In Responses of Forest Ecosystems to Environmental Changes. Eds. A Teller, P Mathy, J N R Jeffers. pp. 829-830. Elsevier, London.

Raspe S, Feger K H and Zöttl H W 1994 Project Arinus: Distribution and nutritional status of fine roots following experimental treatments. KfK/ PEF-Berichte 117, 13-27.

Reddy A S N 2001 Calcium: silver bullet in signaling. Plant Sci. $160,381-404$

SAEFL 1999 Sustainability assessment of Swiss forest policy. Environmental Documentation. Eds. S Limacher, D Kübler, I Kissling-Näf, W Zimmermann. pp. 1-194. Swiss Agency for Environment, Forest and Landscape (SAEFL).

Salih N and Andersson F 1999 Nutritional status of a Norway spruce stand in SW Sweden in response to compensatory fertilization. Plant Soil 209, 85-100.

Schulze E D and Freer-Smith P H 1990 An evaluation of forest decline based on field observations focused on Norway spruce. Proc. R. Soc. Edinb. Sect. B 97, 155-168.

SMA 1998 Annalen der Schweizerischen Meteorologischen Anstalt. SMA. Nr. 135. 144 pp.

Stefan K, Fürst A, Hacker R and Bartels U 1997 Forest foliar condition in Europe (survey 1995 and data from previous years). EC, UN/ECE, Austrian Federal Forest Research Centre. 207 pp.

Stienen H and Bauch J 1988 Element content in tissues of spruce seedlings from hydroponic cultures simulating acidification and deacidification. Plant Soil 106, 231-238.

Stober C, George E and Persson H 2000 Root growth and response to nitrogen. In Carbon and Nitrogen Cycling in European Forest Ecosystems. Eds. E D Schulze. pp. 99-121. Ecological Studies 142, Springer, Berlin.

Strubelt F, Münzenberger B and Hüttl R F 1998 Estimating fine root production of scots pine stands. In Changes of Atmospheric Chemistry and Effects on Forest Ecosystem - A Roof Experiment without a Roof. Eds. R F Hüttl, K Bellmann. pp. 119-136. Kluwer, Dordrecht.

Vance E D 1996 Land application of wood-fired and combination boiler ashes: An overview. J. Environ. Qual. 25, 937-944.

Zhan G, Erich M S and Ohno T 1996 Release of trace elements from wood ash by nitric acid. Wat. Air Soil Pollut. 88, 297-311.

Zimmermann S and Frey B 2002 Soil respiration and microbial properties in an acid forest soil: effects of wood ash. Soil Biol. Biochem. 34, 1727-1737. 